\title{
Effects of amphetamine exposure during adolescence on behavior and prelimbic cortex neuron activity in adulthood
}

\author{
Luke K. Sherrill $^{1}$ and Joshua M. Gulley ${ }^{1,2,3}$ \\ ${ }^{1}$ Department of Psychology, University of Illinois, Urbana-Champaign \\ ${ }^{2}$ Neuroscience Program, University of Illinois, Urbana-Champaign \\ ${ }^{3}$ Carl R. Woese Institute for Genomic Biology, University of Illinois, Urbana-Champaign
}

\begin{abstract}
Repeated exposure to psychostimulants during adolescence produces long-lasting changes in behavior that may be mediated by disrupted development of the mesocorticolimbic dopamine system. Here, we tested this hypothesis by assessing the effects of amphetamine (AMPH) and dopamine receptor-selective drugs on behavior and neuron activity in the prelimbic region of the medial prefrontal cortex (PFC). Adolescent male, Sprague-Dawley rats were given saline or 3 $\mathrm{mg} / \mathrm{kg}$ AMPH between postnatal day (P) 27 and P45. In Experiment 1, locomotor behavior was assessed during adulthood following challenges with a dopamine $\mathrm{D}_{1}$ (SKF 82958) or $\mathrm{D}_{2}$ (quinpirole) receptor-selective agonist. In Experiment 2, pre-exposed rats were challenged during adulthood with AMPH and a $\mathrm{D}_{1}$ (SKF 83566) or $\mathrm{D}_{2}$ (eticlopride) receptor-selective antagonist. In Experiment 3, the activity of putative pyramidal cells in the prelimbic cortex was recorded as rats behaved in an open-field arena before and after challenge injections with AMPH and one of the antagonists. We found that compared to controls, adolescent pre-exposed rats were more sensitive to the stimulant effects of AMPH and the dopamine receptor agonists, as well as to the ability of the antagonists to reverse AMPH-induced stereotypy. Prelimbic neurons from AMPH pre-exposed rats were also more likely to respond to an AMPH challenge in adulthood, primarily by reducing their activity, and the antagonists reversed these effects. Our results suggest that exposure to AMPH during adolescence leads to enduring adaptations in the mesocorticolimbic dopamine system that likely mediate heightened response to the drug during adulthood.
\end{abstract}

\section{Keywords}

adolescent; development; $\mathrm{D}_{1}$ receptor; $\mathrm{D}_{2}$ receptor; locomotor activity; sensitization

Corresponding author: Joshua M. Gulley, Ph.D., Department of Psychology and Neuroscience Program, University of Illinois at Urbana-Champaign, 731 Psychology Bldg MC-716, 603 E Daniel St, Champaign IL 61820 USA. Tel: 001 (217) 265-6413; Fax: 001 (217) 244-5876; jgulley@illinois.edu.

Publisher's Disclaimer: This is a PDF file of an unedited manuscript that has been accepted for publication. As a service to our customers we are providing this early version of the manuscript. The manuscript will undergo copyediting, typesetting, and review of the resulting proof before it is published in its final citable form. Please note that during the production process errors may be discovered which could affect the content, and all legal disclaimers that apply to the journal pertain. 


\section{Introduction}

Individuals with a long history of $\mathrm{AMPH}^{*}$ misuse often exhibit impairments in tasks assessing executive cognitive functions such as impulse control, attention, working memory, and decision-making (McKetin and Mattick, 1998; Ornstein et al., 2000; Monterosso et al., 2005; Woods et al., 2005; Casaletto et al., 2015). Notably, however, cognitive impairment is not an inevitable consequence of repeated AMPH exposure (Scott et al., 2007; Hart et al., 2012) and the development of drug-induced cognitive dysfunction may depend on a number of ancillary factors. One such potential factor is the initial age of drug exposure, with those beginning drug use during adolescence being most at risk (Vonmoos et al., 2013). This hypothesis is supported indirectly by data showing that brain regions known to be important for cognition, including those in the corticolimbic circuitry such as the PFC, amygdala, and hippocampus, are among the last to develop adult-like structure and function, and appear highly susceptible to environmental influences such as drug use (Paus et al., 2008; Gulley and Juraska, 2013). In addition, cross-sectional analyses have suggested that those with the longest duration of psychostimulant abuse, which are individuals who started drug use in early adolescence, are the most susceptible to deficits in decision making (Rogers et al., 1999) and have a greater likelihood of developing a substance use disorder (Wu and Schlenger, 2003; Lopez-Quintero et al., 2011; Gilder et al., 2014).

The mechanisms that underlie this enhanced vulnerability of adolescents to the adverse consequences of repeated AMPH exposure are uncertain, but a leading candidate is druginduced changes in the normal development of the mesocorticolimbic dopamine system (Gulley and Juraska, 2013). Studies in rodents have demonstrated that during adolescent development, there are significant changes in the density of monoamine transporters and dopaminergic fibers (Kalsbeek et al., 1988; Benes et al., 2000; Moll et al., 2000; Willing et al., 2017). Dopamine neurons in the VTA, which project to multiple areas including the PFC and NAc, have been shown to be more active during the adolescent period compared to adulthood and this appears to be due to a relatively reduced GABAergic tone in the adolescent VTA (McCutcheon et al., 2012). This finding is not unequivocal, however, as a recent study reported no age-dependent differences in baseline firing rates of VTA dopamine neurons (Kim et al., 2016). This study also showed neurons recorded from adolescents were less responsive to reward anticipation and delivery compared to those recorded from adults. In terms of receptors for dopamine, there is an overproduction and subsequent decline of dopamine $\mathrm{D}_{1}$ and $\mathrm{D}_{2}$ receptor expression in the PFC and NAc as rats age from preadolescence into young adulthood (Andersen et al., 2000; Tarazi and Baldessarini, 2000; Brenhouse et al., 2008). It has also been suggested that signaling via $\mathrm{D}_{1}-\mathrm{D}_{2}$ heteromers, particularly in the striatum and NAc, is also unique in adolescents compared to adults and this may contribute to enhanced vulnerability in adolescents to the effects of abused drugs (Perreault et al., 2014).

In the current study, we tested the hypothesis that repeated exposure to AMPH during periadolescence (P27-P45) leads to long-lasting changes in the function of $\mathrm{D}_{1}$ and $\mathrm{D}_{2}$ receptors in adulthood. In Experiment 1, we investigated if adult rats pre-exposed to AMPH

\footnotetext{
*AMPH - amphetamine; PFC - prefrontal cortex; VTA - ventral tegmental area; NAc - nucleus accumbens; P - postnatal day
} 
in periadolescence were sensitized to the motor-activating effects of the $\mathrm{D}_{1}$-selective agonist SKF 82958 or the $\mathrm{D}_{2}$-selective agonist quinpirole compared to saline-treated controls. In a second experiment, we tested if the $\mathrm{D}_{1}$-selective antagonist SKF 83566 or the $\mathrm{D}_{2}$-selective antagonist eticlopride would differentially influence AMPH-induced stereotypy in periadolescent pre-exposed rats compared to controls. Lastly, in Experiment 3 we used in vivo electrophysiology in periadolescent pre-exposed rats and controls to investigate functional changes in putative pyramidal cells of the prelimbic region of the medial PFC. Previous studies have revealed an important role of the medial PFC in AMPH-induced motor activation and sensitization (Steketee, 2003; Hall et al., 2009; Gulley and Stanis, 2010; Mathews and McCormick, 2012; Aguilar-Rivera et al., 2015). Moreover, the activity of pyramidal output cells is tightly regulated by $D_{1}$ and $D_{2}$ receptors (Seamans and Yang, 2004) and we recently found that periadolescent AMPH exposure alters $D_{1}$ receptormediated inhibition in these cells in vitro (Kang et al., 2016a; Paul et al., 2016).

\section{Results}

\subsection{Experiment 1 - Effects of AMPH pre-exposure on $D_{1}$ and $D_{2}$ agonist challenge}

Relative to baseline, there was an increase in motor activity after injection with the $\mathrm{D}_{1}$ agonist SKF 82958 in both controls and AMPH pre-exposed rats (Fig. 1). For ambulation, we found a significant main effect of time bin $\left(\mathrm{F}_{8,168}=16.7, p<0.001\right)$ and a significant group $\mathrm{x}$ time bin interaction $\left(\mathrm{F}_{8,168}=6.30, p<0.001\right)$. As shown in Fig. 1a, rats pre-exposed to AMPH had a significantly greater maximal response that persisted for the entire 90-min post-drug interval. The $\mathrm{D}_{1}$ agonist also increased stereotypy (Fig. 1b) and rearing (Fig. 1c) behavior. Separate ANOVAs indicated significant main effects of time bin for stereotypy $\left(\mathrm{F}_{8,168}=5.79, p<0.001\right)$ and rearing $\left(\mathrm{F}_{8,168}=4.54, p<0.001\right)$. However, in contrast to ambulation, there were no significant main effects of group or group $\mathrm{x}$ time bin interactions ( $p s>0.05)$.

During challenge sessions with the $\mathrm{D}_{2}$ agonist quinpirole, rats pre-exposed to AMPH were more sensitive to drug-induced increases in ambulation (Fig. 2a). Two-way repeated measures ANOVA of these data revealed significant main effects of group $\left(\mathrm{F}_{1,21}=6.76, p<\right.$ $0.05)$ and time bin $\left(\mathrm{F}_{8,168}=97.5, p<0.001\right)$, as well as a significant group $\mathrm{x}$ time bin interaction $\left(\mathrm{F}_{8,168}=4.97, p<0.001\right)$. Pre-exposed rats showed a significant increase in agonist-induced ambulatory activity beginning $30 \mathrm{~min}$ post-injection, while the activity of control animals did not significantly change across the $90 \mathrm{~min}$ post-injection period. Similarly, analysis of stereotypy (Fig. 2b) indicated a significant main effect of time bin $\left(\mathrm{F}_{8,168}=22.3, p<0.001\right)$ and a significant group $\mathrm{x}$ time bin interaction $\left(\mathrm{F}_{8,168}=6.88, p<\right.$ 0.001). For rearing (Fig. 2c), there was a significant main effect of time bin $\left(\mathrm{F}_{8,168}=10.1, p\right.$ $<0.001$ ) and a group $\mathrm{x}$ time bin interaction that was at the threshold for being considered statistically significant $\left(\mathrm{F}_{8,168}=1.20, p=0.053\right)$. Thus, for all three measures of motor activity, AMPH pre-exposed rats exhibited greater sensitivity to the effects of quinpirole. 


\subsection{Experiment 2 - Effects of $A M P H$ pre-exposure on $A M P H$ and $D_{1}$ or $D_{2}$ antagonist challenge}

In a separate group of rats, we assessed the effects of AMPH pre-exposure on the response to a challenge injection of AMPH and to subsequent injection with a $\mathrm{D}_{1}$ or $\mathrm{D}_{2}$ antagonist. As shown in Fig. 3, a challenge injection of $3 \mathrm{mg} / \mathrm{kg}$ AMPH significantly increased motor activity regardless of pre-exposure; however, AMPH pre-exposed rats exhibited significantly less AMPH-induced ambulation than controls (Fig. 3a). A two-way repeated measures ANOVA on these data indicated significant main effects of group $\left(\mathrm{F}_{1,100}=10.7, p<0.01\right)$ and time bin $\left(\mathrm{F}_{5,500}=179.9, p<0.001\right)$, as well as a significant group $\mathrm{x}$ time bin interaction $\left(\mathrm{F}_{5,500}=15.4, p<0.001\right)$. This relative reduction in ambulation was likely a result of response competition, as AMPH-induced stereotypy was significantly greater in pre-exposed rats relative to controls (Fig. 3b). Two-way repeated measures ANOVA of stereotypy indicated significant main effects of group $\left(\mathrm{F}_{1,100}=33.6, p<0.001\right)$ and time bin $\left(\mathrm{F}_{5,50}=\right.$ $60.3, p<0.001)$, as well as a significant group $\mathrm{x}$ time bin interaction $\left(\mathrm{F}_{5,500}=10.6, p<\right.$ 0.001 ). Rearing behavior followed a similar trend to ambulation, with pre-exposed rats rearing less than controls after AMPH (Fig. 3c). Two-way repeated measures ANOVA on these data revealed significant main effects of group $\left(\mathrm{F}_{1,100}=14.9, p<0.001\right)$ and time bin $\left(\mathrm{F}_{5,500}=88.9, p<0.001\right)$, and a significant group $\mathrm{x}$ time bin interaction $\left(\mathrm{F}_{5,500}=20.4, p<\right.$ $0.001)$.

The effects of the dopamine receptor antagonists on AMPH-induced stereotypy were assessed after challenge injections with either saline, SKF 83566 ( $D_{1}$ antagonist), or eticlopride ( $\mathrm{D}_{2}$ antagonist). As shown in Fig. 4 , the cumulative stereotypy response was greater in pre-exposed rats relative to controls, and continued to increase across the session in pre-exposed rats given saline at challenge. In rats given SKF 83566 (Fig. 4a) or eticlopride (Fig. 4b) at this challenge injection, however, this continued increase in stereotypy across the session was blocked. A three-way repeated measures ANOVA on these data indicated significant main effects of group $\left(\mathrm{F}_{1,96}=8.09, p<0.01\right)$ and challenge $\left(\mathrm{F}_{8,768}\right.$ $=136.0, p<0.001)$, and a significant group $\mathrm{x}$ challenge interaction $\left(\mathrm{F}_{16,768}=1.71, p<\right.$ $0.05)$. There was no effect of challenge on stereotypy in controls that received saline during adolescence ( $p$-values $>0.05)$.

\subsection{Experiment 3 - Effects of AMPH pre-exposure on medial PFC neuron activity}

A total of 417 neurons were recorded from the medial PFC of control and AMPH preexposed rats $(n=5 /$ group $)$ during two open-field challenge sessions. All electrodes were localized to the prelimbic region (Fig. 5a), with recordings from individual neurons isolated and analyzed with NeuroExplorer (Fig. 5b). During baseline (15 min prior to AMPH injection), we found no significant differences in mean firing rate across the two recording sessions so these data were collapsed. Moreover, the baseline activity of the 202 units recorded from controls $(2.98 \pm 0.18$ spikes $/ \mathrm{sec})$ was not significantly different from that recorded in the 215 units from pre-exposed rats $(3.17 \pm 0.17$ spikes/sec $)$.

Cells were classified as increased, decreased, or not changed based on modulations in firing rate after AMPH challenge (Fig. 6a). In both control and AMPH pre-exposed rats, the majority of recorded prelimbic neurons (> 78\%) were responsive to $3 \mathrm{mg} / \mathrm{kg}$ AMPH. Of 
these AMPH-responsive units, the most frequent response-type was a decrease in firing rate post-injection (Fig. 6b). We found a significant difference between groups in the population distribution of unit responses $\left(\chi^{2}=13.56, p<0.01\right)$. In pre-exposed animals relative to controls, there was a greater proportion of units that decreased firing rate after AMPH injection and a smaller proportion showing no change. The percentage of cells excited by AMPH was similar in the two groups.

Separate analyses of decreased and increased units revealed that the magnitude of change was greatest in the AMPH pre-exposed group (Fig. 7). For decreased units, there were main effects of group $\left(\mathrm{F}_{1,226}=8.12, p<0.01\right)$ and time $\left(\mathrm{F}_{11,2486}=158.9, p<0.001\right)$, as well as a group $\mathrm{x}$ time interaction $\left(\mathrm{F}_{11,2486}=22.6, p<0.001\right)$. For increased units, there was a main effect of time $\left(\mathrm{F}_{11,1353}=18.0, p<0.001\right)$ and a group $\mathrm{x}$ time interaction $\left(\mathrm{F}_{11,1353}=2.12, p\right.$ $<0.05)$. Between-group differences in response magnitude were significant by $20 \mathrm{~min}$ after AMPH injection and persisted for the duration of the recording period in units that had druginduced decreases in firing rate (Fig. 7a). For those with drug-induced increases (Fig. 7b), where responses in pre-exposed rats were more variable, between-group differences were statistically significant by 25 min after injection.

At 45 min after they were administered $\mathrm{AMPH}$, rats were given an injection of the $\mathrm{D}_{1^{-}}$ selective antagonist SKF $83566(0.03 \mathrm{mg} / \mathrm{kg})$ or the $\mathrm{D}_{2}$-selective antagonist eticlopride $(0.03$ $\mathrm{mg} / \mathrm{kg}$ ) to assess the ability of these drugs to alter AMPH-induced changes in medial PFC firing rate. As shown in Fig. 8, data were analyzed by comparing the mean normalized firing rate during the last $15 \mathrm{~min}$ of the 45-min AMPH response interval to the same measure during the last $15 \mathrm{~min}$ of the 45-min antagonist response interval. For the $\mathrm{D}_{1}$ antagonist, we found a significant main effect of injection $\left(\mathrm{F}_{1,99}=10.9, p=0.001\right)$ and a near-significant main effect of group $\left(\mathrm{F}_{1,99}=3.43, p=0.067\right)$ in decreased units (Fig. 8a); there was only a significant main effect of injection $\left(\mathrm{F}_{1,62}=4.33, p<0.05\right)$ for increased units (Fig. 8b). For the $\mathrm{D}_{2}$ antagonist, we found a significant main effect of injection $\left(\mathrm{F}_{1,124}=24.8, p<0.001\right)$ and a near-significant main effect of group $\left(\mathrm{F}_{1,124}=3.03, p=0.084\right)$ in decreased units (Fig. $8 \mathrm{a}$ ); none of the main effects or the interaction was significant for increased units (Fig. $8 \mathrm{~b}$ ). Thus, both antagonists tended to reverse AMPH-induced changes in firing rate, but this effect was most robust for the $\mathrm{D}_{1}$-selective compound SKF 83566 in units that decreased firing rate after AMPH. Moreover, the effect was similar in control and pre-exposed rats.

In addition to the analysis of firing rate, burst firing activity of prelimbic neurons was also assessed during each recording session. Separate two-way repeated measures ANOVAs for bursting rate revealed significant main effects of injection during both sessions (SKF 83566: $\mathrm{F}_{2,400}=15.5, p<0.001$; eticlopride: $\left.\mathrm{F}_{2,436}=40.5, p<0.001\right)$ and a significant group $\mathrm{x}$ injection interaction $\left(\mathrm{F}_{2,400}=4.38, p<0.05\right)$ for the first session when the $\mathrm{D}_{1}$ antagonist was administered. As shown in Fig. 9a, spontaneous bursting after saline injections in the first test session was blunted in pre-exposed animals relative to controls. This effect of preexposure was evident in the second test session (Fig. 9b), but the group difference was reduced and not statistically significant. In both sessions, bursting rate tended to decrease after injections of $3 \mathrm{mg} / \mathrm{kg}$ AMPH, particularly in controls. AMPH-induced reductions in bursting rate were relatively unaffected by challenges with either antagonist. 
Analysis of the percentage of spikes occurring in bursts also revealed effects of AMPH and antagonist challenges, but these varied depending on the recording session. In the session where the $\mathrm{D}_{1}$ antagonist was tested, we found a significant group $\mathrm{x}$ injection interaction $\left(\mathrm{F}_{2,400}=4.00, p<0.05\right)$. As shown in Fig. 9c, prelimbic units recorded from pre-exposed rats had in increase in the percentage of spikes occurring in bursts after AMPH injection and this was reversed after injection with the SKF 83566. In the session where the $\mathrm{D}_{2}$ antagonist was tested (Fig. 9d), we found a significant main effect of time $\left(\mathrm{F}_{2,436}=14.0, p<0.001\right)$, and a near significant group $\mathrm{x}$ injection interaction $\left(\mathrm{F}_{2,436}=2.97, p=0.052\right)$. Thus, in both groups there was a significant increase in the percentage of spikes occurring in bursts and this effect was reversed to a statistically significant extent in the pre-exposed group of rats.

\section{Discussion}

The developing dopamine system of the adolescent brain may be an especially vulnerable target of the plasticity induced by repeated drug exposure. In the current study, we tested the hypothesis that AMPH exposure during periadolescence induces changes in dopamine receptors that would persist into adulthood, lead pre-exposed rats to be more sensitive to the behavioral effects of AMPH and dopamine receptor-selective drugs, and alter the function of putative pyramidal cells in the prelimbic region of the medial PFC. In Experiment 1, we found that AMPH pre-exposed rats, compared to controls, were more sensitive to the motor activating effects of the $\mathrm{D}_{1}$ agonist SKF 82958 and the $\mathrm{D}_{2}$ agonist quinpirole. With the $\mathrm{D}_{1}$ agonist, this sensitization was isolated to ambulation, whereas the $\mathrm{D}_{2}$ agonist induced a relatively greater effect on both ambulation and stereotypy. In Experiment 2, we found that pre-exposed rats were more sensitive to the stereotypy-inducing effects of AMPH as well as to the ability of a $\mathrm{D}_{1}$ or $\mathrm{D}_{2}$ antagonist to attenuate AMPH-induced stereotypy. Lastly, our electrophysiological recordings of prelimbic neurons (Experiment 3) revealed that cells recorded from pre-exposed rats, compared to those from controls, were less likely to be firing in bursts under baseline conditions. Following an AMPH challenge, these neurons were also more likely to be inhibited by AMPH, they exhibited a greater magnitude of change from baseline firing, and they were more sensitive to $\mathrm{D}_{1}$ and $\mathrm{D}_{2}$ antagonist-induced reversal of AMPH's effects on burst firing. Together, these results support the hypothesis that AMPH exposure during adolescence alters the development of the dopaminergic system, and in particular $\mathrm{D}_{1}$ and $\mathrm{D}_{2}$ receptor function, such that in adulthood animals are more sensitive to the neural and behavioral effects of drugs that influence dopamine receptor function.

It has been known for some time that rats pre-exposed to AMPHs in adulthood will exhibit behavioral sensitization to $\mathrm{D}_{2}$, but not $\mathrm{D}_{1}$, receptor-selective agonists after long withdrawal periods (Levy et al., 1988; Ujike et al., 1990; Vanderschuren et al., 1999). Here, we show that AMPH exposure during adolescence leads to a sensitized response to both $\mathrm{D}_{1}$ and $\mathrm{D}_{2}$ receptor-selective agonists when challenges are given in adulthood. This suggests that drug exposure during adolescence, which is a developmental stage when these receptors are overproduced and subsequently pruned (Andersen et al., 2000; Tarazi and Baldessarini, 2000; Brenhouse et al., 2008), may lead to unique changes in dopamine receptor expression and/or function compared to drug exposure during adulthood. Supporting this hypothesis, we recently showed that the same AMPH exposure protocol we used here induced a 
reduction of $\mathrm{D}_{1}$ expression in the medial PFC (Kang et al., 2016b) and inhibited $\mathrm{D}_{1^{-}}$mediated inhibition of pyramidal cell output in the medial PFC (Kang et al., 2016a) when assessed in adulthood. Also consistent is our current finding that adult rats exposed to AMPH during adolescence were more sensitive to the effects of dopamine receptor-selective antagonists on AMPH-induced stereotypy.

A comparison of the effects of the different receptor-selective drugs on ambulation and stereotypy in pre-exposed rats suggests that adolescent AMPH exposure may have a differential impact on $\mathrm{D}_{1}$ and $\mathrm{D}_{2}$ receptors. We found the $\mathrm{D}_{1}$ agonist SKF 82958 tended to induce a greater potentiation of ambulation, whereas the $\mathrm{D}_{2}$ agonist quinpirole had a greater effect on stereotypy. Previous work in adult male rats demonstrated that the $0.5 \mathrm{mg} / \mathrm{kg}$ dose of quinpirole used here tends to suppress locomotor activity in lieu of more repetitive behaviors such as sniffing (Horvitz et al., 2001), so the relatively reduced effect on ambulation may not be surprising. However, adolescent rats are reported to be more sensitive to the effects of quinpirole compared to adults (Frantz and Van Hartesveldt, 1999). A recent study comparing $\mathrm{D}_{1}$ and $\mathrm{D}_{2}$ agonist responses in adolescent and adult male rats (Dwyer and Leslie, 2016)showed adolescents are more sensitive to both the ambulation- and stereotypyinducing effects of quinpirole, but not to the effects of $\mathrm{D}_{1}$ agonists. Thus, it might be the case that exposure to AMPH during development induces a functional state of relative $\mathrm{D}_{2}$ receptor supersensitivity. This would be consistent with our previous findings of reduced $\mathrm{D}_{1}$ receptor expression in the mPFC (Kang et al., 2016b) and a reduced ability of the $\mathrm{D}_{1}$ agonist SKF 38393 to increase spontaneous inhibitory postsynaptic currents in the mPFC (Kang et al., 2016a) following exposure to AMPH during adolescence. However, this hypothesis requires future study, especially since the current experiments did not investigate a full doseresponse curve for the agonist drugs that were used. Moreover, automated methods of assessing stereotypy have limitations with regard to the amount of information that can be obtained about the unique components of repetitive behaviors (Rebec and Bashore, 1984).

Previous work revealed that when AMPH-exposed adolescents were given an AMPH challenge in adulthood, they exhibit sensitized locomotor responses (McPherson and Lawrence, 2006; Mathews et al., 2011; Labonte et al., 2012; Richetto et al., 2013; Shanks et al., 2015) and stereotypy (Hankosky et al., 2013; Sherrill et al., 2013). However, it was not previously demonstrated that dopamine receptor antagonists could partially reverse this sensitized response in adolescent-exposed rats or that $D_{1}$ and $D_{2}$ receptor-selective antagonists were similarly efficacious. Activation of $\mathrm{D}_{1}$, and to a lesser extent $\mathrm{D}_{2}$ receptors, is known to be important for the induction of AMPH sensitization (Ujike et al., 1989; Vezina, 1996; Meng et al., 1998; Karper et al., 2002; Tanabe et al., 2004; Tournier et al., 2013; Kai et al., 2015), but their relative roles in its expression have been less well characterized. The fewer number of studies investigating expression of sensitization have analyzed adult-exposed rats after relatively short withdrawal periods ( $\leq 14$ days) and suggest a more prominent role for $\mathrm{D}_{1}$ receptors (Shuto et al., 2006; Shi and McGinty, 2011) or a $\mathrm{D}_{1^{-}}$$\mathrm{D}_{2}$ heteromer (Shen et al., 2015). The current findings are suggestive of an enhanced sensitivity of the developing adolescent brain to the ability of AMPH to induce enduring changes in the function of $\mathrm{D}_{1}$ and $\mathrm{D}_{2}$ receptors in the $\mathrm{PFC}$, though this hypothesis will require further investigation with comparison groups of subjects that are outside the window of adolescent development when they are exposed to the drug (e.g., juveniles and adults). 
Our electrophysiology results suggest that AMPH-induced adaptations in the prelimbic cortex play a role in the behavioral adaptations we observed. Previously, neurons in the prelimbic and infralimbic regions of the medial PFC from AMPH-exposed adult rats were shown to be more responsive to AMPH compared to those recorded from controls when a challenge injection was given following a short withdrawal (Homayoun and Moghaddam, 2006; Gulley and Stanis, 2010). In these studies, which like the current experiments were done in freely behaving rats, the effects of AMPH pre-treatment differed depending on dose and withdrawal duration. In the earlier study (Homayoun and Moghaddam, 2006), adult rats were treated for 5 days with $2 \mathrm{mg} / \mathrm{kg}$ AMPH or saline and were subsequently given a 2 $\mathrm{mg} / \mathrm{kg}$ AMPH challenge following a 10-day withdrawal period. The authors reported that compared to controls, neurons from AMPH pre-exposed rats were more responsive to the challenge injection and the most frequent response observed was an inhibition in firing. In experiments from our laboratory (Gulley and Stanis, 2010), adult rats were treated with 1 $\mathrm{mg} / \mathrm{kg}$ AMPH for 5 days and challenged with the same dose following a 4-day withdrawal. Like the earlier study, AMPH pre-exposed rats were more responsive to AMPH and the predominant effect was a decrease in firing rate and bursting. Here, when exposure to a higher dose of AMPH (3 mg/kg) occurred during peri-adolescent development and the AMPH challenge was given $\sim 30$ days later in adulthood, we observed a similar predominance of AMPH-induced decreases in firing rate. Additionally, we found that prelimbic neurons from AMPH pre-exposed rats were more sensitive to $D_{1}$ and $D_{2}$ antagonist-induced reversal of AMPH's effects on burst firing, though the ability of these antagonists to reverse changes in firing rate were similar in pre-exposed and control rats. A similar reversal of AMPH's effects on neural activity in behaving rats was previously reported in recordings from dorsal striatum (Rosa-Kenig et al., 1993). Together, the previous and current findings suggest that the longer-term adaptations in medial PFC circuitry that AMPH induces likely involve changes in the sensitivity of $D_{1}$ and $D_{2}$ receptors and they may be more pronounced following adolescent exposure or a more protracted withdrawal period. Differentiating between these hypotheses of age or withdrawal duration dependency requires future studies, but our previous in vitro electrophysiology findings support the important role of exposure age for determining the effects of AMPH exposure on PFC neuronal physiology (Kang et al., 2016a; Paul et al., 2016).

The specific mechanisms through which AMPH alters the anatomical and functional development of the PFC during adolescence remains to be elucidated, but several lines of evidence point to an important role for drug-induced changes in the ontogeny of GABAergic signaling. Studies in non-human primates and rodents have revealed that normal PFC development involves significant increases in GABAergic function, including an increase in the expression and excitability of fast-spiking, parvalbumin-positive GABAergic interneurons (Caballero et al., 2014), an increase in spontaneous inhibitory postsynaptic currents in the pyramidal cells on which these interneurons synapse (Hashimoto et al., 2009; Cass et al., 2014), and changes in the subunit composition of $\mathrm{GABA}_{\mathrm{A}}$ receptors that would facilitate inhibitory transmission (Datta et al., 2015). In addition, dopaminergic control of inhibitory signaling in the PFC changes significantly during adolescence. For example, $\mathrm{D}_{1^{-}}$ and $\mathrm{D}_{2}$-mediated increases in GABAergic interneuron excitability occurs sometime between P36 and P50 in male rats (Tseng and O'Donnell, 2007). Our current finding of increased 
burst firing in prelimbic neurons from AMPH pre-exposed rats is consistent with a druginduced change in the adolescent development of GABAergic signaling and/or its control by dopamine receptors, but we did not directly test that hypothesis here. However, we have shown previously that adolescent AMPH exposure impairs $\mathrm{D}_{1}$-mediated inhibition of pyramidal neurons in the PFC (Kang et al., 2016a) and leads to disinhibition in these cells following AMPH challenge in adulthood (Paul et al., 2016). Moreover, comparable effects on GABA and dopamine signaling in the PFC have been reported following adolescent exposure to the dopamine transporter blockers cocaine (Cass et al., 2013) and GBR 12909 (Khan et al., 2017), the substituted amphetamine MDMA (3,4methylendioxymethamphetamine; Cadoni et al., 2017) or the cannabinoid receptor agonist WIN 55,212-2 (Cass et al., 2014)

\section{Conclusion}

The results of the current study and others (Laviola et al., 2001; McPherson and Lawrence, 2006; Labonte et al., 2012; Reynolds et al., 2015; Kang et al., 2016a; Tendilla-Beltrán et al., 2016) point to a key role for drug-induced changes in the structural and functional development of the mesocorticolimbic dopamine system in the neural and behavioral changes induced by adolescent AMPH exposure. One intriguing possibility, which awaits testing, is that the phasic dopamine changes caused by an injection of AMPH have the unique ability to reorganize the structural and functional connections between the VTA and the PFC in adolescents compared to adults. A recent optogenetic study revealed this potential mechanism for heightened mesofrontal circuit plasticity in adolescents compared to adults and further demonstrated that $\mathrm{D}_{2}$ receptors play an important role in regulating this plasticity (Mastwal et al., 2014). Dopamine systems are undoubtedly not alone in being affected by AMPH, however, and long-lasting changes in GABAergic (Cass et al., 2013), glutamatergic (Counotte et al., 2011) and cholinergic (O’Dell, 2009) functioning have also been reported following exposure to AMPHs and other psychostimulants during adolescence.

Because AMPH is used in the treatment of attention deficit hyperactivity disorder (ADHD) in children and adolescents, there is obvious concern about the potential for early-life drug exposure to induce long lasting changes in brain function and behavior. The current study does not address this issue, however, as the exposure dose used here $(3 \mathrm{mg} / \mathrm{kg} /$ day injected i.p.) is likely to be beyond what would be used therapeutically. Future studies that use more clinically relevant dosing of AMPH are clearly warranted. Another important goal of future studies will be to more specifically link drug-induced disruptions with the consequences they induce, especially those related to cognitive dysfunction and other behaviors known to be critically involved in addiction. It will also be important to provide more detailed analysis of the developmental timing of drug exposure as multiple recent studies have revealed that drug exposure during specific times during peri-adolescence can influence later neurophysiological and behavioral outcomes (Adriani et al., 2004; Kang et al., 2016b; Tendilla-Beltrán et al., 2016) and that puberty may influence drug effects on neuronal development differently in males and females (Dagher et al., 2001; Juraska and Willing, 2017). 


\section{Experimental Procedure}

\subsection{Subjects}

The male subjects ( $\mathrm{n}=96$ for all experiments) were offspring of male and female SpragueDawley rats (Harlan, Indianapolis, IN, USA) bred in our animal facility. After weaning at P22, rats were housed 2-3 per cage with food and water available ad libitum. Rats were maintained on a 12:12 hr light/dark cycle (lights on at 0800) and experimental procedures were conducted during the light phase. All experimental procedures were approved by the Institutional Animal Care and Use Committee at the University of Illinois, UrbanaChampaign, and were in accordance with the Guide for the Care and Use of Laboratory Animals (National Research Council, 2011).

\subsection{Open-field Apparatus}

Locomotor activity was monitored in open-field arenas $(41 \times 41 \times 41 \mathrm{~cm})$ constructed of transparent acrylic walls and surrounded by photobeam frames (Coulbourn Instruments; Allentown, PA, USA) that recorded horizontal (lower frame; $2.5 \mathrm{~cm}$ above the arena floor) and vertical activity (upper frame; $15 \mathrm{~cm}$ above the arena floor). Each open-field arena was housed in a sound-attenuating cubicle $(76 \times 80 \times 63 \mathrm{~cm})$ that contained a $76 \mathrm{~mm}$ speaker fixed to one side wall to provide white noise $(70 \mathrm{~dB})$, two ceiling mounted white lights ( $4 \mathrm{~W}$ each), and a centrally mounted overhead camera (not used in this study). Computer software (TruScan v 2.01, Coulbourn Instruments) was used to record photobeam breaks and to calculate ambulation (m), rearing (number), and stereotypy. Stereotypy was measured as total number of repetitive movements, as defined by the recording software.

\subsection{Drugs}

D-amphetamine sulfate and SKF 82958 hydrobromide ( $\mathrm{D}_{1}$ agonist) were purchased from Sigma-Aldrich (St. Louis, MO, USA). SKF 83566 hydrobromide ( $\mathrm{D}_{1}$ antagonist), eticlopride hydrochloride $\left(\mathrm{D}_{2}\right.$ antagonist), and (-) quinpirole hydrochloride $\left(\mathrm{D}_{2}\right.$ agonist $)$ were purchased from Tocris (Minneapolis, MN, USA). All drugs were dissolved in sterile saline $(0.9 \% \mathrm{NaCl})$. Dosages were calculated based on the weight of the salt and given via intraperitoneal (i.p.) injection at a volume of $1 \mathrm{ml} / \mathrm{kg}$.

\subsection{Pre-treatment}

At weaning, rats were assigned to exposure groups so that animals from 12 litters were represented similarly across groups. Cagemates (2-3 rats/cage) were assigned to the same treatment groups; controls were given $0.9 \%$ saline $(1 \mathrm{ml} / \mathrm{kg})$ and rats in the pre-exposed group were administered AMPH (3 mg/kg). Beginning on P27, one injection was given every other day for a total of 10 injections. For each injection, rats were transferred from the colony to a testing room, and placed individually into acrylic tubs $(46 \times 25 \times 22 \mathrm{~cm})$ lined with hardwood bedding where they remained undisturbed for $60 \mathrm{~min}$ post-injection.

\subsection{Experiment 1}

Approximately 30 days after their last pre-exposure injection (P70-P80), rats $(n=23)$ were transferred from the colony to a separate testing room where they remained in their 
homecages for a 30-min acclimation period. Next, they were placed individually in an openfield arena for $15 \mathrm{~min}$, then removed and injected with $1 \mathrm{ml} / \mathrm{kg}$ saline. They were immediately returned to the open-field and $30 \mathrm{~min}$ later challenged with either a dopamine $\mathrm{D}_{1}\left(\mathrm{SKF} 82958,1.0 \mathrm{mg} / \mathrm{kg}\right.$ ) or a $\mathrm{D}_{2}$ (quinpirole, $0.5 \mathrm{mg} / \mathrm{kg}$ ) receptor agonist. Assignment of the specific agonist was made randomly. Doses were chosen based on previous studies showing they were near or above threshold for affecting behavior in rats pre-exposed to AMPH in adulthood (Vanderschuren et al., 1999).

Following agonist injections, rats were allowed to behave undisturbed for $90 \mathrm{~min}$ and then were returned to their homecage. Three days later, the drug challenge procedure was repeated, but rats received the dopamine receptor agonist they did not get during the first drug challenge. The order of drug challenges was counterbalanced within each group (i.e. control and pre-exposed).

\subsection{Experiment 2}

Approximately 30 days after the last pre-exposure (P70-P80), rats $(n=51)$ were given two challenge sessions that were separated by three days. During the first session, rats were placed individually in an open-field arena for $15 \mathrm{~min}$, then removed and injected with 1 $\mathrm{ml} / \mathrm{kg}$ saline (Injection 1). Thirty min later, they were administered $3 \mathrm{mg} / \mathrm{kg}$ AMPH (Injection 2) and allowed to freely move about the chamber for another $45 \mathrm{~min}$. Lastly, rats were challenged (Injection 3) with saline, a dopamine $\mathrm{D}_{1}$ antagonist (SKF 83566, $0.03 \mathrm{mg}$ / $\mathrm{kg}$ ), or a $\mathrm{D}_{2}$ antagonist (eticlopride, $0.03 \mathrm{mg} / \mathrm{kg}$ ) and monitored for an additional $45 \mathrm{~min}$. These doses were chosen based on previous studies showing they would decrease AMPHinduced stereotypy (Garrett and Holtzman, 1994; Fritts et al., 1997). This procedure was repeated three days later during a second session. However, rats in the antagonist challenge groups were given the antagonist for Injection 3 that they did not receive during the first challenge session; the order of injections was assigned randomly. Rats previously challenged with saline on session one received saline again for Injection 3.

\subsection{Data analysis for Experiments 1 and 2}

In Experiment 1, ambulation, stereotypy, and rearing measures were summed in 15-min bins and analyzed using separate two-way ANOVAs, with time bin as the within-subjects factor and group (control, pre-exposed) as the between-subjects factor. Similarly, in Experiment 2, ambulation, stereotypy, and rearing measures were summed and analyzed using separate two-way ANOVAs with time bin as the within-subjects factor and between-subjects factors of group (control, pre-exposed). Cumulative stereotypy, which was obtained for each rat by summing this measure for the 45-min period after injections with AMPH and challenge drugs (i.e., saline or the dopamine receptor antagonists), was analyzed with three-way mixed factor ANOVAs with injection as the within-subjects factor and between-subjects factors of group (control, pre-exposed) and challenge drug (saline, SKF 83566, eticlopride). Main effects and interactions were further analyzed using Holm-Sidak multiple comparison procedures. Statistical analyses were conducted using R Statistical Computing Software (R: a Foundation for Statistical Computing; Vienna, Austria) or Systat 11 (Systat Software Inc.; San Jose, CA, USA). 


\subsection{Experiment 3}

Rats ( $\mathrm{n}=5$ /group) underwent surgical procedures for implantation of microwire electrode arrays between P65 and P70 using methods we described previously (Gulley and Stanis, 2010). The array, which was implanted using stereotaxic coordinates for the prelimbic region of the medial PFC (3.0 mm AP, $0.7 \mathrm{~mm} \mathrm{ML}$, and 3.5mm DV to bregma; Paxinos and Watson, 2007) consisted of eight Teflon-insulated stainless steel wires (50- $\mu \mathrm{m}$ diameter each) arranged in a $2 \times 4$ pattern (NB Labs; Denison, TX, USA). Rats were allowed to recover from surgery for $\geq 5$ days.

Between P70 and P80, which was approximately 30 days after the last pre-exposure injection, rats were transferred from the colony to a separate testing room, where they remained in their homecages for a 30-min acclimation period. During this time, voltage signals from each microwire were amplified with a unity gain field effect transistor (FET) headstage and transmitted via a shielded lightweight cable connected to a multi-channel commutator, which allowed the animal to freely move about the testing environment during recording sessions. Extracellular signals were amplified, band-pass filtered $(250 \mathrm{~Hz}$ to 8 $\mathrm{kHz}$ ), and digitally captured with a $40 \mathrm{kHz}$ sampling rate using a Multichannel Acquisition Processor (Plexon Inc.; Dallas, TX, USA). Single-unit activity originating from putative pyramidal cells was identified based on waveform (i.e. spike) characteristics using well established criteria (Jung et al., 1998; Barthó et al., 2004; Homayoun et al., 2005; Homayoun and Moghaddam, 2006; Gulley and Stanis, 2010). Spike sorting was also performed both online and offline from continuous data using both manual and automated procedures (Sort Client and Offline Sorter; Plexon Inc.). Single-units were discriminated if the absolute refractory period of the target signal was $>1.1 \mathrm{~ms}$ and the waveform amplitude was at least 2.5:1 above background. Units with an average firing rate $>10$ spikes/s, which were putative fast spiking interneurons, made up a small percentage of the total units recorded in this study $(\sim 7 \%)$ were thus excluded from analysis.

Rats were subsequently placed into an open-field arena for $15 \mathrm{~min}$, then removed and injected i.p. with $1 \mathrm{ml} / \mathrm{kg}$ saline. Thirty minutes later, they were administered $3 \mathrm{mg} / \mathrm{kg}$ AMPH and allowed to freely move about the chamber for another $45 \mathrm{~min}$. Lastly, they were injected with the $\mathrm{D}_{1}$ antagonist SKF $83566(0.03 \mathrm{mg} / \mathrm{kg}$, i.p.) and monitored for an additional $45 \mathrm{~min}$. During a second recording session, which took place two days after the first, the same procedure was used except the last injection given to rats was the $\mathrm{D}_{2}$ antagonist eticlopride $(0.03 \mathrm{mg} / \mathrm{kg}$, i.p.).

\subsection{Experiment 3 data analysis}

Electrophysiological data were imported into NeuroExplorer (NEX Technologies, Madison, AL, USA) and analyzed with custom scripts and methods similar to those used previously in our lab and others (Homayoun and Moghaddam, 2006; Gulley and Stanis, 2010). Neurons recorded during sessions 1 and 2 were treated as independent units, although the anchoring of the electrode connectors to the skull leaves the possibility that the same or similar population of cells were sampled across sessions. Baseline firing rates, which were designated as the mean activity (in $\mathrm{Hz}$ ) during the saline phase of each recording session (15-min period after saline injection and before AMPH injection), were analyzed with two- 
way repeated measures ANOVA (group x session). The 99\% confidence interval for this baseline period was then used to classify each unit's response to AMPH. A unit was categorized as "increased" or "decreased" after AMPH if its activity post-injection was above or below, respectively, the $99 \%$ confidence interval for (1) five of the nine 5-min recording bins, or (2) at least four consecutive 5-min bins post-injection (Gulley and Stanis, 2010). Those units not meeting one of these criteria were classified as "not changed". The distribution of response types was compared between the control and pre-exposed groups using chi-square $\left(\chi^{2}\right)$.

To compare the magnitude change after AMPH challenge during sessions 1 and 2 combined, mean firing rate was calculated for each unit in 5-min bins and activity was normalized to each unit's baseline (mean firing during the 15-min saline injection period). This was done by dividing the unit's mean firing rate by its mean baseline firing rate and then expressing the value as a percentage. These data were subsequently analyzed with separate two-way repeated measures ANOVAs (group x time) for increased and decreased response types. The ability of $\mathrm{D}_{1}$ and $\mathrm{D}_{2}$ antagonists to alter AMPH-induced changes in firing rate were analyzed by comparing the mean normalized firing rate (\% baseline) for the last $15 \mathrm{~min}$ of the AMPH injection interval to the last $15 \mathrm{~min}$ of the antagonist response interval. These data were then analyzed with separate two-way mixed factor repeated measures ANOVAs (group $\mathrm{x}$ injection) for each response type (increased or decreased) and antagonist (SKF 83566 or eticlopride). For all ANOVA tests, main effects and interactions were further analyzed using Holm-Sidak multiple comparison procedures where appropriate.

To analyze burst firing, spike train data were analyzed with the NeuroExplorer using the Poisson surprise method, which is robust against irregular patterns of activity and changes in mean firing rate that may obscure burst detection (Legéndy and Salcman, 1985; Homayoun et al., 2005; Homayoun and Moghaddam, 2006). A minimum surprise value of 5 was set as the confidence level for detection. For each unit, bursting rate (bursts/min) and the percent of spikes in bursts were compared between groups using separate two-way repeated measures ANOVAs (group $\mathrm{x}$ injection). Significant differences were followed-up with Holm post-hoc comparisons where appropriate. Statistical analyses for data obtained in Experiment 3 were conducted using SigmaPlot 12.5 (Systat Software Inc.; San Jose, CA, USA).

\section{Acknowledgments}

The authors thank Tanya Krishnamani and Dylan O’Hearn for their excellent technical assistance.

Funding

This research was supported in part by a grant from the National Institutes of Health through the National Institute on Drug Abuse (grant number DA 029815).

\section{References}

Adriani W, Granstrem O, Macri S, Izykenova G, Dambinova S, Laviola G. Behavioral and neurochemical vulnerability during adolescence in mice: studies with nicotine. Neuropsychopharmacology. 2004; 29:869-878. [PubMed: 14666123] 
Aguilar-Rivera MI, Casanova JP, Gatica RI, Quirk GJ, Fuentealba JA. Amphetamine sensitization is accompanied by an increase in prelimbic cortex activity. Neuroscience. 2015; 288:1-9. [PubMed: 25542419]

Andersen SL, Thompson AT, Rutstein M, Hostetter JC, Teicher MH. Dopamine receptor pruning in prefrontal cortex during the periadolescent period in rats. Synapse. 2000; 37:167-169. [PubMed: 10881038]

Barthó P, Hirase H, Monconduit L, Zugaro M, Harris KD, Buzsáki G. Characterization of neocortical principal cells and interneurons by network interactions and extracellular features. J Neurophysiol. 2004; 92:600-608. [PubMed: 15056678]

Benes FM, Taylor JB, Cunningham MC. Convergence and plasticity of monoaminergic systems in the medial prefrontal cortex during the postnatal period: implications for the development of psychopathology. Cereb Cortex. 2000; 10:1014-1027. [PubMed: 11007552]

Brenhouse HC, Sonntag KC, Andersen SL. Transient D1 dopamine receptor expression on prefrontal cortex projection neurons: relationship to enhanced motivational salience of drug cues in adolescence. J Neurosci. 2008; 28:2375-2382. [PubMed: 18322084]

Caballero A, Flores-Barrera E, Cass DK, Tseng KY. Differential regulation of parvalbumin and calretinin interneurons in the prefrontal cortex during adolescence. Brain Struct Funct. 2014; 219:395-406. [PubMed: 23400698]

Cadoni C, Pisanu A, Simola N, Frau L, Porceddu PF, Corongiu S, Dessì C, Sil A, Plumitallo A, Wardas J, Di Chiara G. Widespread reduction of dopamine cell bodies and terminals in adult rats exposed to a low dose regimen of MDMA during adolescence. Neuropharmacology. 2017; 123:385-394. [PubMed: 28603026]

Casaletto KB, Obermeit L, Morgan EE, Weber E, Franklin DR, Grant I, Woods SP. Depression and executive dysfunction contribute to a metamemory deficit among individuals with methamphetamine use disorders. Addict Behav. 2015; 40:45-50. [PubMed: 25222847]

Cass DK, Flores-Barrera E, Thomases DR, Vital WF, Caballero A, Tseng KY. CB1 cannabinoid receptor stimulation during adolescence impairs the maturation of GABA function in the adult rat prefrontal cortex. Mol Psychiatry. 2014; 19:536-543. [PubMed: 24589887]

Cass DK, Thomases DR, Caballero A, Tseng KY. Developmental disruption of gamma-aminobutyric acid function in the medial prefrontal cortex by noncontingent cocaine exposure during early adolescence. Biol Psychiatry. 2013; 74:490-501. [PubMed: 23558299]

Counotte DS, Goriounova Na, Li KW, Loos M, van der Schors RC, Schetters D, Schoffelmeer ANM, Smit AB, Mansvelder HD, Pattij T, Spijker S. Lasting synaptic changes underlie attention deficits caused by nicotine exposure during adolescence. Nat Neurosci. 2011; 14:417-419. [PubMed: 21336271]

Dagher A, Bleicher C, Aston Ja, Gunn RN, Clarke PB, Cumming P. Reduced dopamine D1 receptor binding in the ventral striatum of cigarette smokers. Synapse. 2001; 42:48-53. [PubMed: 11668590]

Dwyer JB, Leslie FM. Adolescent maturation of dopamine D1 and D2 receptor function and interactions in rodents. PLoS One. 2016; 11:e0146966. [PubMed: 26784516]

Frantz KJ, Van Hartesveldt C. The locomotor effects of quinpirole in rats depend on age and gender. Pharmacol Biochem Behav. 1999; 64:821-826. [PubMed: 10593206]

Fritts ME, Mueller K, Morris L. Amphetamine-induced locomotor stereotypy in rats is reduced by a D1 but not a D2 antagonist. Pharmacol Biochem Behav. 1997; 58:1015-1019. [PubMed: 9408208]

Garrett BE, Holtzman SG. D1 and D2 dopamine receptor antagonists block caffeine-induced stimulation of locomotor activity in rats. Pharmacol Biochem Behav. 1994; 47:89-94. [PubMed: 7906891]

Gilder DA, Gizer IR, Lau P, Ehlers CL. Stimulant dependence and stimulant-associated psychosis: clinical characteristics and age of onset in a native American community sample. J Addict Med. 2014; 8:241-248. [PubMed: 24755633]

Gulley JMM, Juraska JMM. The effects of abused drugs on adolescent development of corticolimbic circuitry and behavior. Neuroscience. 2013; 249:3-20. [PubMed: 23711583] 
Gulley JMM, Stanis JJJ. Adaptations in medial prefrontal cortex function associated with amphetamine-induced behavioral sensitization. Neuroscience. 2010; 166:615-624. [PubMed: 20035836]

Hall DA, Powers JP, Gulley JM. Blockade of D1 dopamine receptors in the medial prefrontal cortex attenuates amphetamine- and methamphetamine-induced locomotor activity in the rat. Brain Res. 2009; 1300:51-57. [PubMed: 19733155]

Hankosky ER, Kofsky NM, Gulley JM. Age of exposure-dependent effects of amphetamine on behavioral flexibility. Behav Brain Res. 2013; 252:117-125. [PubMed: 23756139]

Hart CL, Marvin CB, Silver R, Smith EE. Is Cognitive Functioning Impaired in Methamphetamine Users? A Critical Review. Neuropsychopharmacology. 2012; 37:586-608. [PubMed: 22089317]

Homayoun H, Jackson ME, Moghaddam B. Activation of metabotropic glutamate 2/3 receptors reverses the effects of NMDA receptor hypofunction on prefrontal cortex unit activity in awake rats. J Neurophysiol. 2005; 93:1989-2001. [PubMed: 15590730]

Homayoun H, Moghaddam B. Progression of cellular adaptations in medial prefrontal and orbitofrontal cortex in response to repeated amphetamine. J Neurosci. 2006; 26:8025-8039. [PubMed: 16885216]

Horvitz JC, Williams G, Joy R. Time-dependent actions of D2 family agonist quinpirole on spontaneous behavior in the rat: dissociation between sniffing and locomotion. Psychopharmacology (Berl). 2001; 154:350-355. [PubMed: 11349387]

Jung MW, Qin Y, McNaughton BL, Barnes CA. Firing characteristics of deep layer neurons in prefrontal cortex in rats performing spatial working memory tasks. Cereb Cortex. 1998; 8:437450. [PubMed: 9722087]

Juraska JM, Willing J. Pubertal onset as a critical transition for neural development and cognition. Brain Res. 2017; 1654:87-94. [PubMed: 27060769]

Kai N, Nishizawa K, Tsutsui Y, Ueda S, Kobayashi K. Differential roles of dopamine D1 and D2 receptor-containing neurons of the nucleus accumbens shell in behavioral sensitization. $\mathbf{J}$ Neurochem. 2015; 135:1232-1241. [PubMed: 26442961]

Kalsbeek A, Voorn P, Buijs RM, Pool CW, Uylings HB. Development of the dopaminergic innervation in the prefrontal cortex of the rat. J Comp Neurol. 1988; 269:58-72. [PubMed: 3361004]

Kang S, Paul K, Hankosky ER, Cox CL, Gulley JM. D1 receptor-mediated inhibition of medial prefrontal cortex neurons is disrupted in adult rats exposed to amphetamine in adolescence. Neuroscience. 2016a; 324:40-49. [PubMed: 26946269]

Kang S, Wu MM, Galvez R, Gulley JM. Timing of amphetamine exposure in relation to puberty onset determines its effects on anhedonia, exploratory behavior, and dopamine D1 receptor expression in young adulthood. Neuroscience. 2016b; 339:72-84. [PubMed: 27702645]

Karper PE, De La Rosa H, Newman ER, Krall CM, Nazarian A, McDougall SA, Crawford CA. Role of D1-like receptors in amphetamine-induced behavioral sensitization: A study using d1a receptor knockout mice. Psychopharmacology (Berl). 2002; 159:407-414. [PubMed: 11823893]

Khan A, de Jong LAW, Kamenski ME, Higa KK, Lucero JD, Young JW, Behrens MM, Powell SB. Adolescent GBR12909 exposure induces oxidative stress, disrupts parvalbumin-positive interneurons, and leads to hyperactivity and impulsivity in adult mice. Neuroscience. 2017; 345:166-175. [PubMed: 27890827]

Kim Y, Simon NW, Wood J, Moghaddam B. Reward Anticipation Is Encoded Differently by Adolescent Ventral Tegmental Area Neurons. Biol Psychiatry. 2016; 79:878-886. [PubMed: 26067679]

Labonte B, McLaughlin RJ, Dominguez-Lopez S, Bambico FRR, Lucchino I, Ochoa-Sanchez R, Leyton M, Gobbi G. Adolescent amphetamine exposure elicits dose-specific effects on monoaminergic neurotransmission and behaviour in adulthood. Int J Neuropsychopharmacol. 2012; 15:1319-1330. [PubMed: 22053980]

Laviola G, Pascucci T, Pieretti S. Striatal dopamine sensitization to d-amphetamine in periadolescent but not in adult rats. Pharmacol Biochem Behav. 2001; 68:115-124. [PubMed: 11274716]

Legéndy CR, Salcman M. Bursts and recurrences of bursts in the spike trains of spontaneously active striate cortex neurons. J Neurophysiol. 1985; 53:926-939. [PubMed: 3998798] 
Levy AD, Kim JJ, Ellison GD. Chronic amphetamine alters D-2 but not D-1 agonist-induced behavioral responses in rats. Life Sci. 1988; 43:1207-1213. [PubMed: 3262805]

Lopez-Quintero C, Pérez de los Cobos J, Hasin DS, Okuda M, Wang S, Grant BF, Blanco C. Probability and predictors of transition from first use to dependence on nicotine, alcohol, cannabis, and cocaine: results of the National Epidemiologic Survey on Alcohol and Related Conditions (NESARC). Drug Alcohol Depend. 2011; 115:120-130. [PubMed: 21145178]

Mastwal S, Ye Y, Ren M, Jimenez DV, Martinowich K, Gerfen CR, Wang KH. Phasic dopamine neuron activity elicits unique mesofrontal plasticity in adolescence. J Neurosci. 2014; 34:94849496. [PubMed: 25031392]

Mathews IZ, Kelly H, McCormick CM. Low doses of amphetamine lead to immediate and lasting locomotor sensitization in adolescent, not adult, male rats. Pharmacol Biochem Behav. 2011; 97:640-646. [PubMed: 21108958]

Mathews IZ, McCormick CM. Role of medial prefrontal cortex dopamine in age differences in response to amphetamine in rats: Locomotor activity after intra-mPFC injections of dopaminergic ligands. Dev Neurobiol. 2012; 72:1415-1421. [PubMed: 22081646]

McCutcheon JE, Conrad KL, Carr SB, Ford Ka, McGehee DS, Marinelli M. Dopamine neurons in the ventral tegmental area fire faster in adolescent rats than in adults. J Neurophysiol. 2012; 108:16201630. [PubMed: 22723669]

McKetin R, Mattick RP. Attention and memory in illicit amphetamine users: comparison with nondrug-using controls. Drug Alcohol Depend. 1998; 50:181-184. [PubMed: 9649970]

McPherson CS, Lawrence AJ. Exposure to amphetamine in rats during periadolescence establishes behavioural and extrastriatal neural sensitization in adulthood. Int J Neuropsychopharmacol. 2006; 9:377-392. [PubMed: 16316481]

Meng ZH, Feldpaush DL, Merchant KM. Clozapine and haloperidol block the induction of behavioral sensitization to amphetamine and associated genomic responses in rats. Mol Brain Res. 1998; 61:39-50. [PubMed: 9795122]

Moll GH, Mehnert C, Wicker M, Bock N, Rothenberger A, Ruther E, Huether G. Age-associated changes in the densities of presynaptic monoamine transporters in different regions of the rat brain from early juvenile life to late adulthood. Brain Res brain Res. 2000; 119:251-257.

Monterosso JR, Aron AR, Cordova X, Xu J, London ED. Deficits in response inhibition associated with chronic methamphetamine abuse. Drug Alcohol Depend. 2005; 79:273-277. [PubMed: 15967595]

O'Dell LE. A psychobiological framework of the substrates that mediate nicotine use during adolescence. Neuropharmacology. 2009; 56(Suppl 1):263-278. [PubMed: 18723034]

Ornstein TJ, Iddon JL, Baldacchino AM, Sahakian BJ, London M, Everitt BJ, Robbins TW. Profiles of cognitive dysfunction in chronic amphetamine and heroin abusers. Neuropsychopharmacology. 2000; 23:113-126. [PubMed: 10882838]

Paul K, Kang S, Cox CL, Gulley JM. Repeated exposure to amphetamine during adolescence alters inhibitory tone in the medial prefrontal cortex following drug re-exposure in adulthood. Behav Brain Res. 2016; 309:9-13. [PubMed: 27085589]

Paus TTT, Keshavan M, Giedd JN. Why do many psychiatric disorders emerge during adolescence? Nat Rev Neurosci. 2008; 9:947-957. [PubMed: 19002191]

Paxinos, G., Watson, C. The rat brain in stereotaxic coordinates. 6. San Diego, CA: Elsevier; 2007.

Perreault ML, O'Dowd BF, George SR. Dopamine $\mathrm{D}_{1}-\mathrm{D}_{2}$ receptor heteromer regulates signaling cascades involved in addiction: potential relevance to adolescent drug susceptibility. Dev Neurosci. 2014; 36:287-296. [PubMed: 24820626]

Rebec GV, Bashore TR. Critical issues in assessing the behavioral effects of amphetamine. Neurosci Biobehav Rev. 1984; 8:153-159. [PubMed: 6145135]

Reynolds LM, Makowski CS, Yogendran SV, Kiessling S, Cermakian N, Flores C. Amphetamine in adolescence disrupts the development of medial prefrontal cortex dopamine connectivity in a DCC-dependent manner. Neuropsychopharmacology. 2015; 40:1101-1112. [PubMed: 25336209]

Richetto J, Feldon J, Riva MA, Meyer U. Comparison of the long-term consequences of withdrawal from repeated amphetamine exposure in adolescence and adulthood on information processing and 
locomotor sensitization in mice. Eur Neuropsychopharmacol. 2013; 23:160-170. [PubMed: 22609316]

Rogers RD, Everitt BJ, Baldacchino A, Blackshaw AJ, Swainson R, Wynne K, Baker NB, Hunter J, Carthy T, Booker E, London M, Deakin JF, Sahakian BJ, Robbins TW. Dissociable deficits in the decision-making cognition of chronic amphetamine abusers, opiate abusers, patients with focal damage to prefrontal cortex, and tryptophan-depleted normal volunteers: evidence for monoaminergic mechanisms. Neuropsychopharmacology. 1999; 20:322-339. [PubMed: 10088133]

Rosa-Kenig A, Puotz JK, Rebec GV. The involvement of D1 and D2 dopamine receptors in amphetamine-induced changes in striatal unit activity in behaving rats. Brain Res. 1993; 619:347351. [PubMed: 8374790]

Scott JC, Woods SP, Matt GE, Meyer RA, Heaton RK, Atkinson JH, Grant I. Neurocognitive effects of methamphetamine: a critical review and meta-analysis. Neuropsychol Rev. 2007; 17:275-297. [PubMed: 17694436]

Seamans JK, Yang CR. The principal features and mechanisms of dopamine modulation in the prefrontal cortex. Prog Neurobiol. 2004; 74:1-57. [PubMed: 15381316]

Shanks RA, Ross JM, Doyle HH, Helton AK, Picou BN, Schulz J, Tavares C, Bryant S, Dawson BL, Lloyd SA. Adolescent exposure to cocaine, amphetamine, and methylphenidate cross-sensitizes adults to methamphetamine with drug- and sex-specific effects. Behav Brain Res. 2015; 281:116124. [PubMed: 25496784]

Shen MYF, Perreault ML, Fan T, George SR. The dopamine D1-D2 receptor heteromer exerts a tonic inhibitory effect on the expression of amphetamine-induced locomotor sensitization. Pharmacol Biochem Behav. 2015; 128:33-40. [PubMed: 25444866]

Sherrill LK, Stanis JJ, Gulley JM. Age-dependent effects of repeated amphetamine exposure on working memory in rats. Behav Brain Res. 2013; 242:84-94. [PubMed: 23291159]

Shi X, McGinty JF. D1 and D2 dopamine receptors differentially mediate the activation of phosphoproteins in the striatum of amphetamine-sensitized rats. Psychopharmacology (Berl). 2011; 214:653-663. [PubMed: 21057772]

Shuto T, Kuroiwa M, Hamamura M, Yabuuchi K, Shimazoe T, Watanabe S, Nishi A, Yamamoto T. Reversal of methamphetamine-induced behavioral sensitization by repeated administration of a dopamine D1 receptor agonist. Neuropharmacology. 2006; 50:991-997. [PubMed: 16563442]

Steketee JD. Neurotransmitter systems of the medial prefrontal cortex: potential role in sensitization to psychostimulants. Brain Res Brain Res Rev. 2003; 41:203-228. [PubMed: 12663081]

Tanabe LM, Suto N, Creekmore E, Steinmiller CL, Vezina P. Blockade of D2 dopamine receptors in the VTA induces a long-lasting enhancement of the locomotor activating effects of amphetamine. Behav Pharmacol. 2004; 15:387-395. [PubMed: 15343065]

Tarazi FI, Baldessarini RJ. Comparative postnatal development of dopamine D(1), D(2) and D(4) receptors in rat forebrain. Int J Dev Neurosci. 2000; 18:29-37. [PubMed: 10708903]

Tendilla-Beltrán H, Arroyo-García LE, Diaz A, Camacho-Abrego I, de la Cruz F, Rodríguez-Moreno A, Flores G. The effects of amphetamine exposure on juvenile rats on the neuronal morphology of the limbic system at prepubertal, pubertal and postpubertal ages. J Chem Neuroanat. 2016; 77:6877. [PubMed: 27208629]

Tournier BB, Steimer T, Millet P, Moulin-Sallanon M, Vallet P, Ibañez V, Ginovart N. Innately low D2 receptor availability is associated with high novelty-seeking and enhanced behavioural sensitization to amphetamine. Int J Neuropsychopharmacol. 2013; 16:1819-1834. [PubMed: 23574629]

Tseng KY, O’Donnell P. Dopamine modulation of prefrontal cortical interneurons changes during adolescence. Cereb Cortex. 2007; 17:1235-1240. [PubMed: 16818475]

Ujike H, Akiyama K, Otsuki S. D-2 but not D-1 dopamine agonists produce augmented behavioral response in rats after subchronic treatment with methamphetamine or cocaine. Psychopharmacology (Berl). 1990; 102:459-464. [PubMed: 2151400]

Ujike H, Onoue T, Akiyama K, Hamamura T, Otsuki S. Effects of selective D-1 and D-2 dopamine antagonists on development of methamphetamine-induced behavioral sensitization.

Psychopharmacology (Berl). 1989; 98:89-92. [PubMed: 2498964] 
Vanderschuren LJMJ, Schoffelmeer ANM, Mulder AH, De Vries TJ. Dopaminergic mechanisms mediating the long-term expression of locomotor sensitization following pre-exposure to morphine or amphetamine. Psychopharmacology (Berl). 1999; 143:244-253. [PubMed: 10353426]

Vezina P. D1 dopamine receptor activation is necessary for the induction of sensitization by amphetamine in the ventral tegmental area. J Neurosci. 1996; 16:2411-2420. [PubMed: 8601820]

Vonmoos M, Hulka LM, Preller KH, Jenni D, Baumgartner MR, Stohler R, Bolla KI, Quednow BB. Cognitive dysfunctions in recreational and dependent cocaine users: Role of attention-deficit hyperactivity disorder, craving and early age at onset. Br J Psychiatry. 2013; 203:35-43. [PubMed: 23703315]

Willing J, Cortes LR, Brodsky JM, Kim T, Juraska JM. Innervation of the medial prefrontal cortex by tyrosine hydroxylase immunoreactive fibers during adolescence in male and female rats. Dev Psychobiol. 2017; 59:583-589. [PubMed: 28561889]

Woods SP, Rippeth JD, Conover E, Gongvatana A, Gonzalez R, Carey CL, Cherner M, Heaton RK, Grant I. Deficient strategic control of verbal encoding and retrieval in individuals with methamphetamine dependence. Neuropsychology. 2005; 19:35-43. [PubMed: 15656761]

Wu L-T, Schlenger WE. Psychostimulant dependence in a community sample. Subst Use Misuse. 2003; 38:221-248. [PubMed: 12625429] 


\section{Highlights}

- $\quad$ Rats exposed to amphetamine in adolescence are hypersensitive to $D_{1}$ and $D_{2}$ agonists

- $\quad$ Adolescent amphetamine exposure enhances antagonist-induced reversal of stereotypy

- Amphetamine decreases prelimbic neuron activity more in adolescentexposed rats 

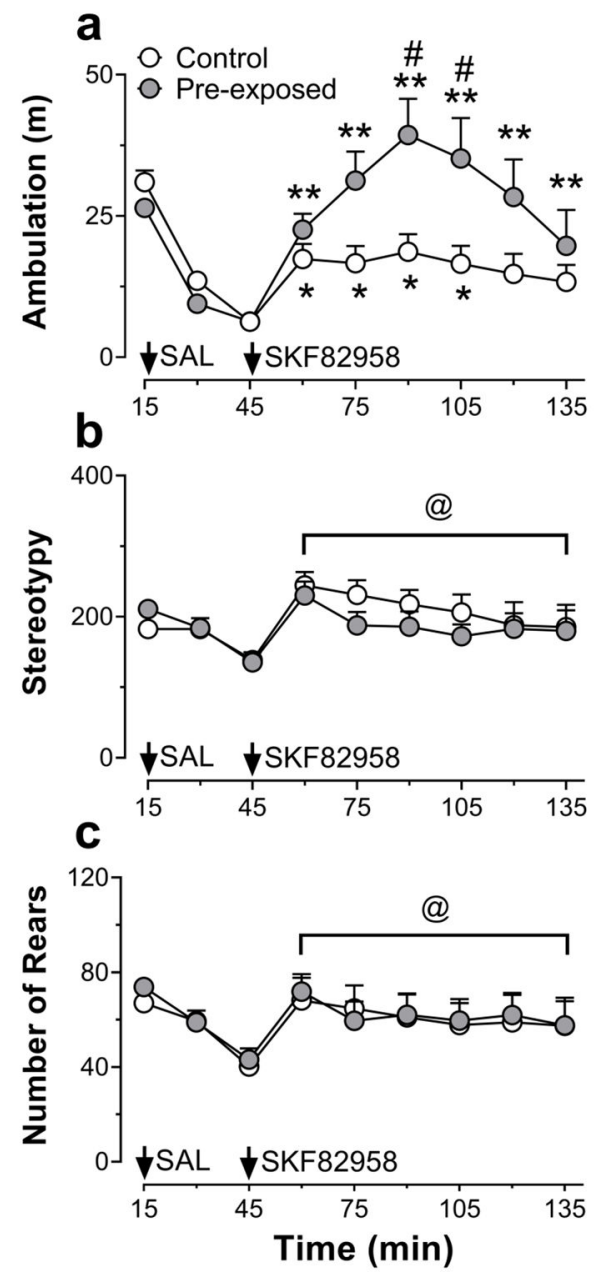

Fig. 1.

Ambulation (a), stereotypy (b) and rearing (c) in an open-field arena following challenge with $1.0 \mathrm{mg} / \mathrm{kg} \mathrm{SKF} 82958$ ( $\mathrm{n}=11-12 /$ group). Arrows indicate time-bins when rats were removed from the open-field and injected (i.p.) with saline and the $\mathrm{D}_{1}$ agonist. $* p<0.05$, $* * p<0.01$ vs baseline (45-min bin) within group; ${ }^{\#} p<0.05$ vs control within time bin; ${ }^{@} p<$ 0.05 vs baseline collapsed across group 

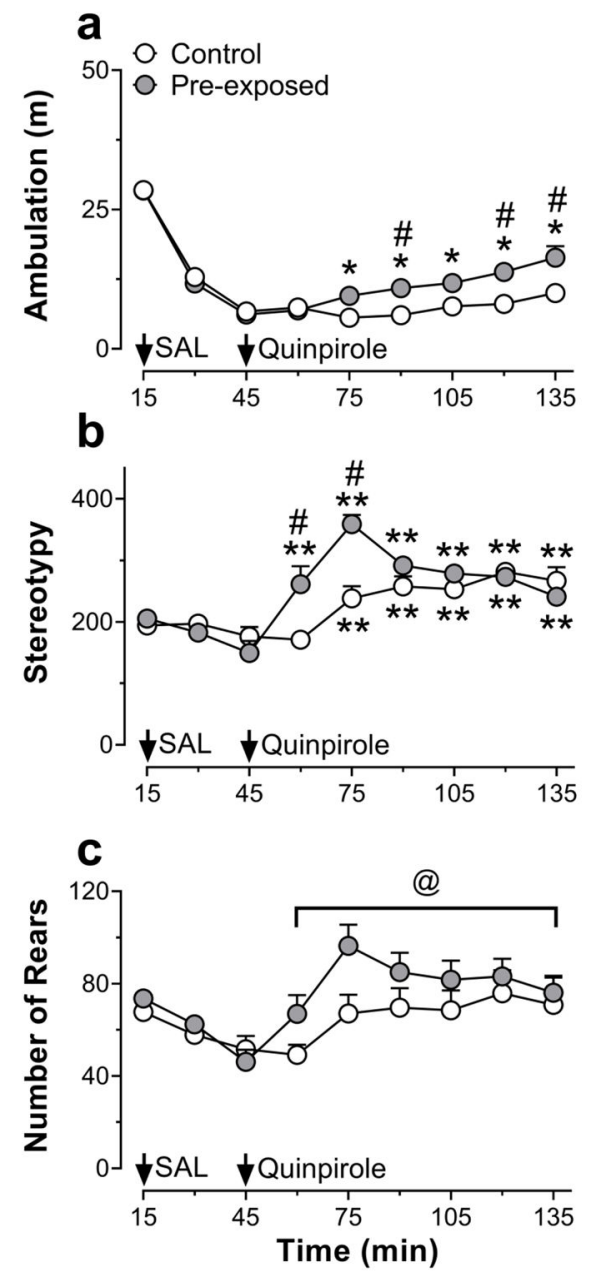

Fig. 2.

Ambulation (a), stereotypy (b) and rearing (c) in an open-field arena following challenge with $0.5 \mathrm{mg} / \mathrm{kg}$ quinpirole ( $\mathrm{n}=11-12 /$ group). Arrows indicate time-bins when rats were removed from the open-field and injected (i.p.) with saline and the $\mathrm{D}_{2}$ agonist. $* p<0.05$, $* * p<0.01$ vs baseline (45-min bin) within group; ${ }^{\#} p<0.05$ vs control within time bin; ${ }^{@} p<$ 0.05 vs baseline collapsed across group 

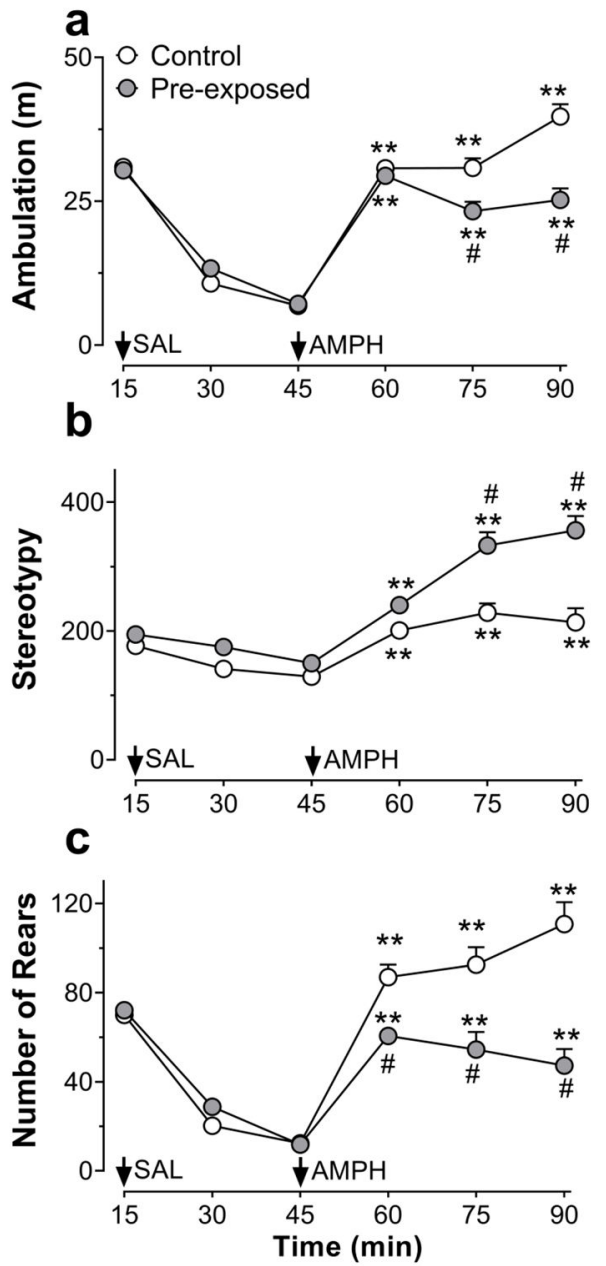

Fig. 3.

Ambulation (a), stereotypy (b) and rearing (c) in an open-field arena following challenge with $3.0 \mathrm{mg} / \mathrm{kg}$ AMPH. Arrows indicate time-bins when rats were removed from the openfield and injected (i.p.) with saline and AMPH. Data are presented collapsed across antagonist treatment group for pre-exposed rats $(\mathrm{n}=25)$ and controls $(\mathrm{n}=26) .{ }^{*} p<0.001$ vs control within time bin, $* * p<0.001$ vs baseline (45-min bin) within group 

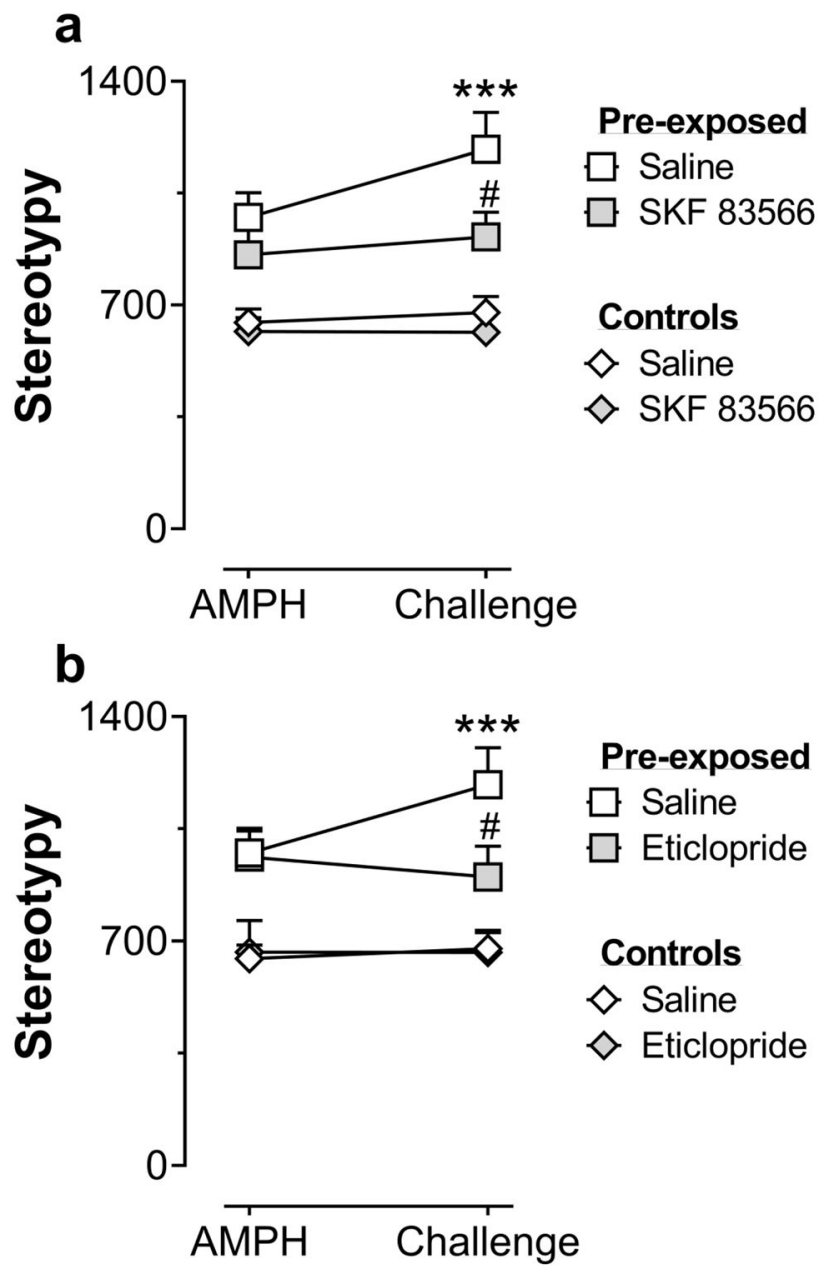

Fig. 4.

Stereotypy following $3.0 \mathrm{mg} / \mathrm{kg}$ AMPH and challenge injections of saline, $0.03 \mathrm{mg} / \mathrm{kg} \mathrm{SKF}$ 83566 (a) or $0.03 \mathrm{mg} / \mathrm{kg}$ eticlopride (b). Data are presented as the cumulative response for the entire 45-min post-injection interval ( $\mathrm{n}=8-9 /$ group). ${ }^{* * *} p<0.001$ vs AMPH period within group; ${ }^{\#} p<0.05$ vs pre-exposed rats given a saline challenge 
a

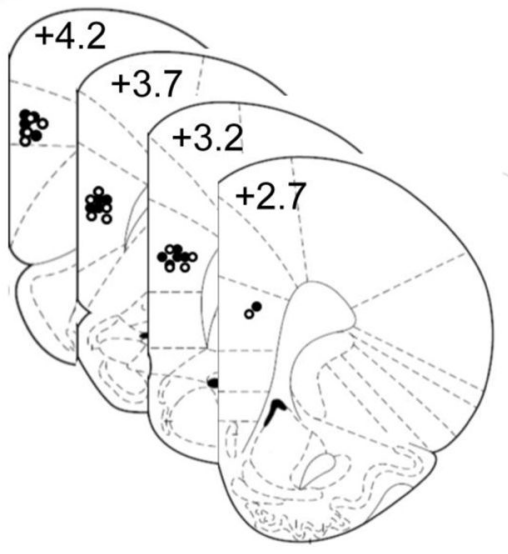

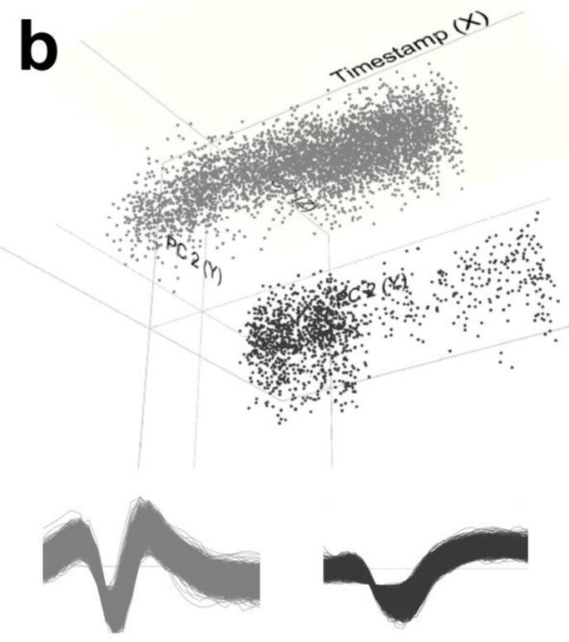

Fig. 5.

Schematic of recording locations in the prelimbic cortex and example sorting of recordings from two putative pyramidal cells. (a) A total of 417 recordings were made from electrodes implanted in the prelimbic region of the medial PFC. Closed circles represent approximate electrode tip locations for AMPH pre-exposed rats, whereas open circles represent locations for controls ( $\mathrm{n}=5$ rats/group). Numbers indicate the distance anterior to bregma (images adapted from Paxinos and Watson 2007). (b) Images taken from the NeuroExplorer data analysis package that show the clustering of two distinct units (indicated in grey and black) based on principle component (PC) analysis of waveform characteristics. PC1 and PC2 are plotted against time and represented in 3-D space. Multiple tracings for waveforms from the two discriminated units are also shown. 
a

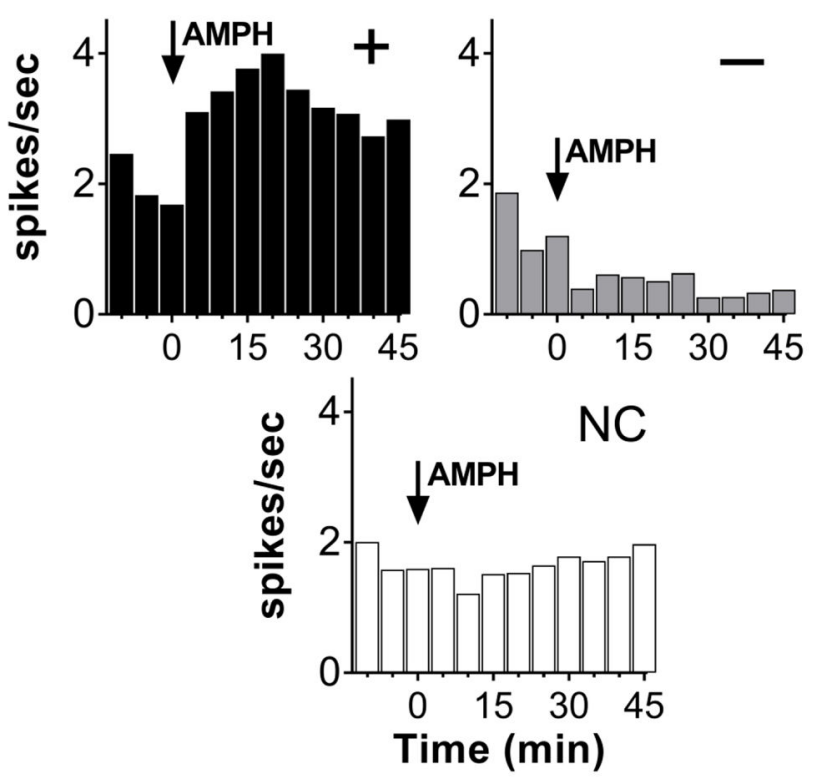

b

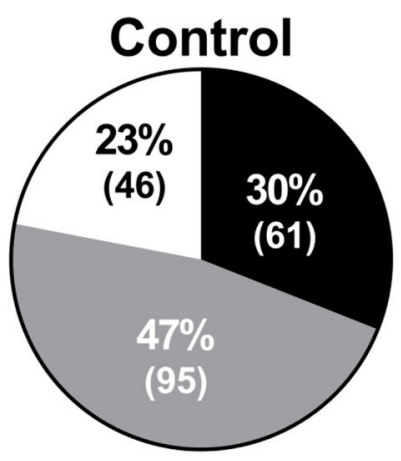

Fig. 6.

Putative pyramidal neurons from the prelimbic cortex that responded to a $3.0 \mathrm{mg} / \mathrm{kg}$ AMPH injection with an increase (+), decrease (-) or no change (NC) in firing rate. (a)

Representative examples of each type of unit response (see Methods for classification procedure). Data are mean firing rate in 5-min bins during a 15-min saline injection baseline and $45 \mathrm{~min}$ after AMPH injection $(\mathrm{t}=0 \mathrm{~min})$. (b) The population distribution of categorized units recorded from control and pre-exposed rats. The number of cells in each category is given in parentheses. Because there were no significant differences in the distribution of response types between recording sessions, data are presented collapsed across sessions. $* * p$ $<0.01, \chi^{2}$ statistic comparing proportion of responses in control and pre-exposed groups 

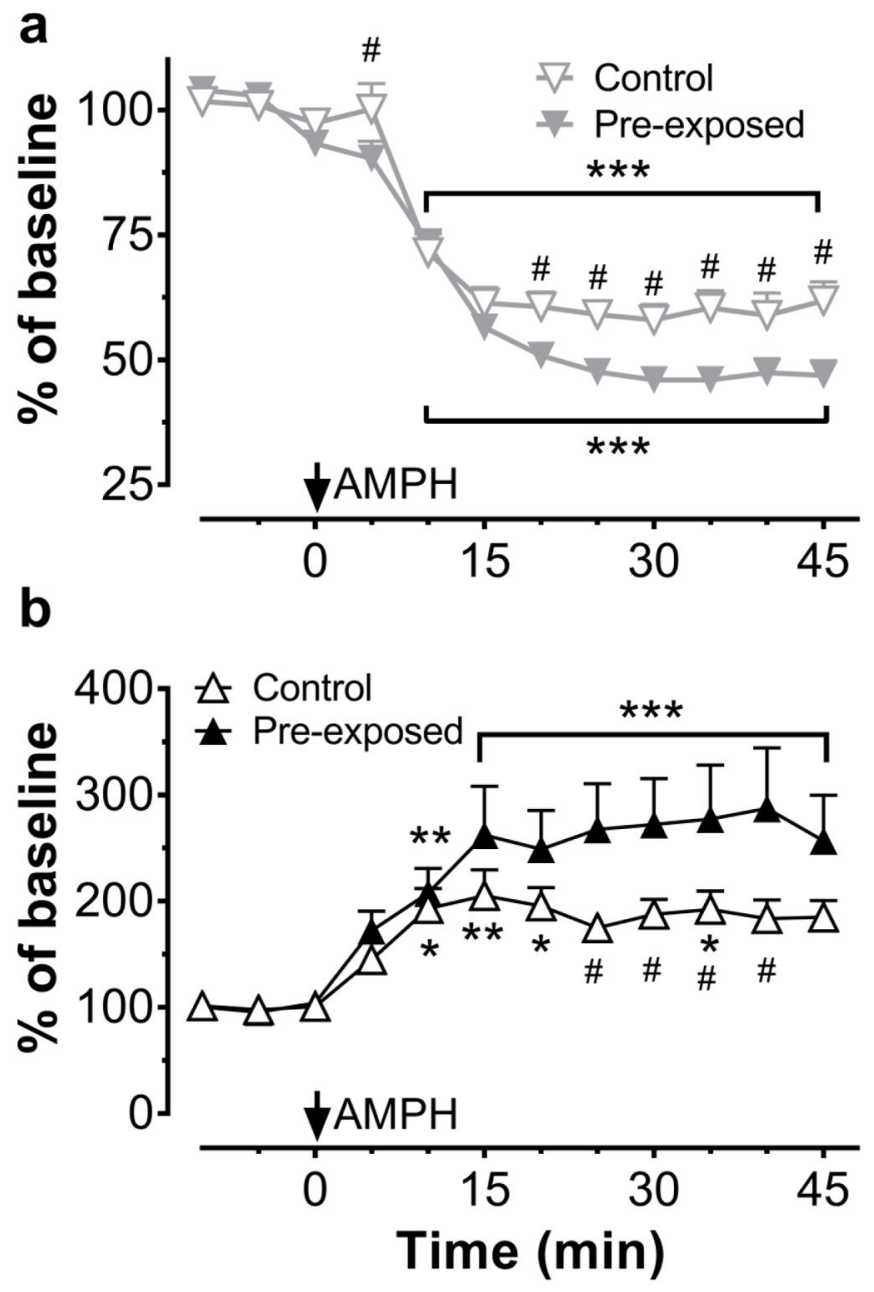

Fig. 7.

Magnitude of firing rate changes in prelimbic cortex cells classified as decreasing (a) or increasing (b) following a challenge injection of $3.0 \mathrm{mg} / \mathrm{kg}$ AMPH (designated by the arrow). Data are normalized to the pre-injection baseline for each unit. $* \mathrm{p}<0.05, * * p<$ 0.01 , and $* * * p<0.001$, vs. the last time bin before AMPH injection $(\mathrm{t}=45 \mathrm{~min})$ within group; ${ }^{\#} p<0.05$ vs. pre-exposed group within time bin 

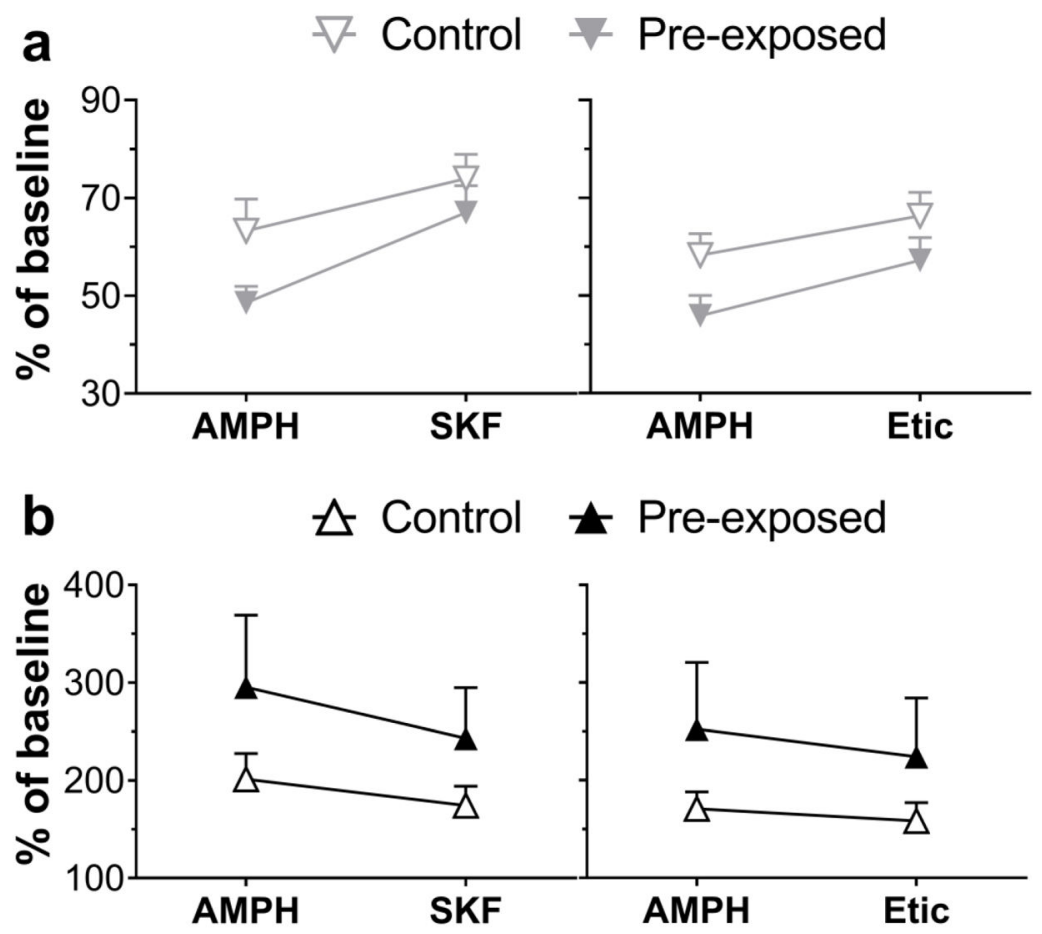

Fig. 8.

Magnitude of firing rate changes in decreased (a) and increased (b) cells during the last 15$\mathrm{min}$ of the 45-min recording period following $3.0 \mathrm{mg} / \mathrm{kg}$ AMPH injection and the last 15 min of the 45-min recording period following the $\mathrm{D}_{1}$ antagonist SKF $83566(0.03 \mathrm{mg} / \mathrm{kg})$ or the $\mathrm{D}_{2}$ antagonist eticlopride $(0.03 \mathrm{mg} / \mathrm{kg})$. Data are normalized to the pre-injection baseline for each unit. 

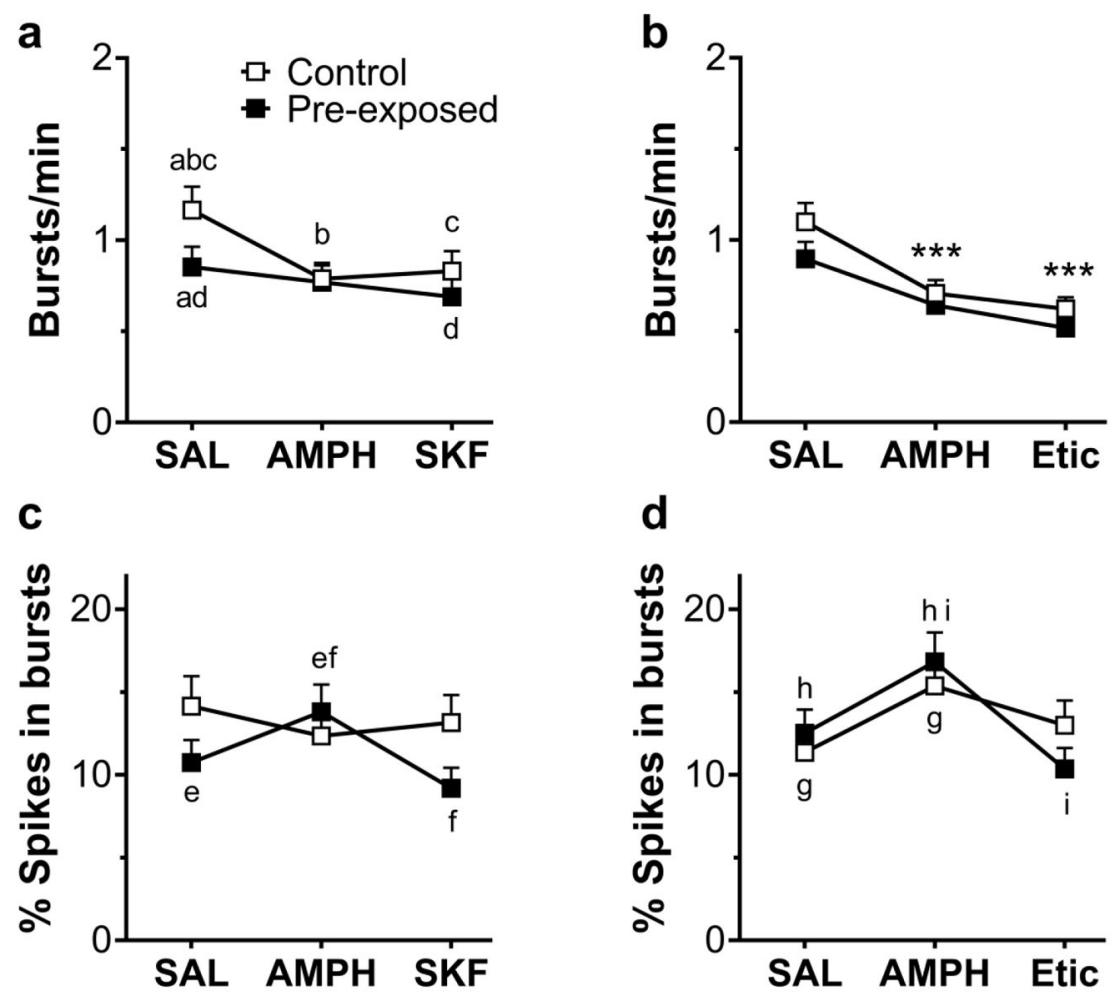

Fig. 9.

Burst firing during saline baseline (SAL), following $3.0 \mathrm{mg} / \mathrm{kg}$ AMPH, and after challenge with the $\mathrm{D}_{1}$ antagonist (SKF 83566; panels a, c) or the $\mathrm{D}_{2}$ antagonist (eticlopride; panels $\mathbf{b}$, d). Matching letters indicate significant between or within-group differences $(p<0.05)$. $* * * p<0.001$ vs SAL, collapsed across group 